\title{
Kajian Tingkat Kerentanan Rajungan (Portunus pelagicus) di Perairan Desa Tunggulsari Kabupaten Rembang
}

\author{
Parameswari Iccha Nirmalabuddhi Wishnuputri*, Sri Redjeki, Retno Hartati \\ Departemen IImu Kelautan, Fakultas Perikanan dan Ilmu Kelautan, Universitas Diponegoro \\ Jl. Prof.H.Soedarto S.H, Tembalang,Semarang, Jawa Tengah 50275 Indonesia \\ ${ }^{*}$ Corresponding author, e-mail : parameswariicha@gmail.com
}

\begin{abstract}
ABSTRAK: Rajungan (Portunus pelagicus) adalah salah satu sumber daya hayati laut Indonesia. Rajungan merupakan komoditas utama perikanan di Indonesa, baik untuk lokal maupun ekspor. Nilai ekonomis rajungan yang tergolong tinggi mengakibatkan penangkapan rajungan dilakukan secara besar-besar dan dapat memicu terjadinya kepunahan. Penelitian bertujuan untuk mengetahui tingkat kerentanan rajungan di Perairan Desa Tunggulsari dan mengetahui karakteristik morfometri dari rajungan yang ditangkap pada lokasi tersebut. Metode yang digunakan dalam penelitian ini adalah metode Productivity and Susceptibility Analysis (PSA). Wawancara dilakukan kepada 60 nelayan di Desa Tunggulsari. Pengukuran parameter kualitas perairan meliputi suhu, oksigen terlarut, salinitas, dan $\mathrm{pH}$. Pengukuran morfometri dilakukan pada salah satu pengepul di desa. Hasil dari wawancara diketahui bahwa nelayan di Desa Tunggulsari menggunakan 2 macam alat tangkap yaitu bubu lipat dan jaring insang dasar. Penilaian atribut produktivitas rajungan masuk dalam kategori tinggi, sedangkan penilaian atribut kerentanan tergolong pada resiko rendah untuk penggunaan kedua alat tersebut. Nilai MSC untuk alat tangkap bubu lipat adalah 96,0 dan 98,2 untuk alat tangkap jaring insang dasar. Nilai MSC > 80 menunjukkan bahwa tingkat kerentanan rajungan pada lokasi tersebut masuk pada kategori rendah. Selanjutnya, pola pertumbuhan rajungan di Desa Tunggulsari adalah allometrik negatif baik untuk rajungan jantan maupun betina. Hal ini menunjukkan pertumbuhan panjang dan lebar karapas lebih cepat dibandingkan penambahan berat rajungan.
\end{abstract}

Kata kunci: Rajungan (Portunus pelagicus); Kerentanan; PSA; Morfometri; Tunggulsari

\section{Blue Swimming Crab (Portunus pelagicus) Vulnerability Study in the Waters of Tunggulsari Village Rembang Regency}

ABSTRACT: The blue swimming crab (Portunus pelagicus) is one of the Indonesian marine biological resources. The blue swimming crab is the primary commodity of fisheries in Indonesia, both for local and export. The economic value of blue swimming crab classified as high involve overexploitation of blue swimming crab and can lead to extinction. This research is aimed to determine the level of vulnerability of blue swimming crab in Tunggulsari waters and to discover morphometry characteristic of blue swimming crab that caught at that location. The method used in this research is Productivity and Susceptibility (PSA) method. Interviews were conducted with six fishers in the village of Tunggulsari. Measurement of water quality parameters, including temperature, dissolved oxygen, salinity, and $\mathrm{pH}$. Morphometry measurement was carried out in one of the collectors in the village. The interview results revealed that fishers in the village of Tunggulsari used two fishing tools, namely Bubu lipat and bottom set gillnet. Assessment of blue swimming crab productivity attributes is included in the high category, while the assessment of vulnerability attributes is classified as low risk for the use of both tools. The MSC value for Bubu lipat is 96,0 and 98,2 for bottom set gillnet. The MSC value is more than 80 indicates that the level of blue swimming crab vulnerability at that location is in a low category. Further, the blue swimming crab growth pattern in the village of Tunggulsari are negative allometric for both male and female blue swimming crabs. This shows the growth in length and width carapace is faster than the addition of blue swimming crab weight.

Keywords: Portunus pelagicus; Vulnerability; PSA; Morphometry; Tunggulsari 


\section{PENDAHULUAN}

Desa Tunggulsari Kabupaten Rembang adalah salah satu daerah produksi rajungan. Mayoritas warga daerah tersebut memiliki profesi sebagai nelayan. Nelayan Tunggulsari sudah lama melakukan penangkapan terhadap rajungan yang dilakukan di sekitar perairan Rembang dengan menggunakan alat tangkap jaring insang dasar dan bubu lipat. Rajungan (Portunus pelagicus) adalah salah satu sumber daya hayati laut Indonesia. Rajungan hidup di pantai bersubstrat pasir, pasir berlumpur, dan di substrat karang. Rajungan dapat berenang dri permukaan laut sampai kedalaman 65 meter, hal ini menjadikan rajungan juga disebut sebagai swimming crab. Rajungan menghabiskan hidupnya dengan membenamkan tubuhnya kedalam pasir dan menonjolkan matanya untuk menunggu mangsa yaitu ikan dan jenis invertebrata yang lain (Ernawati et al., 2016).

Rajungan merupakan salah satu komoditas utama perikanan di Indonesia baik untuk lokal maupun ekspor (Kurnia et al., 2014). Penangkapan yang dilakukan sejak dulu dan secara terusmenerus dapat mengakibatkan kepunahan rajungan apabila tidak dilakukan pengelolaan yang baik. Menurut Setiyowati (2016), rajungan memiliki nilai ekonomis yang tergolong tinggi dan dimanfaatkan di bidang pangan. Hal ini akan mengakibatkan penangkapan rajungan dilakukan secara besarbesaran dan dapat memicu terjadinya overfishing.

Untuk mengelola penangkapan rajungan, diperlukan adanya kajian kerentanan rajungan di perairan tesebut. Kajian kerentanan dapat dilakukan dengan menggunakan metode Productivity and Susceptibility Analysis (PSA). Metode Productivity and susceptibility Analysis (PSA) dilakukan dengan memberikan nilai pada setiap atribut dan nilai tersebut dijadikan sebagai acuan untuk memasukkan suatu spesies ke dalam kategori kerentanan rendah, sedang, atau tinggi. Semakin tinggi nilai kerentanan pada spesies, dalam hal ini rajungan, menunjukkan bahwa kondisi stok di perairan mengalami penurunan dan dapat terancam punah (Patanda et al., 2017). PSA sudah banyak dilakukan untuk mengkaji tingkat kerentanan pada suatu spesies perikanan, seperti pada penelitian yang dilakukan oleh Dudi et al. (2019) yang melakukan kajian tingkat kerentanan tuna sirip kuning (Thunnus albacares) yang didaratkan di TPI Sodohoa, Kendari.

Penangkapan rajungan yang dilakukan secara terus-menerus di Perairan Rembang dapat mengakibatkan kepunahan rajungan. Agar tidak terjadi kepunahan perlu dilakukan pengelolaan sumber daya rajungan dengan melakukan kajian kerentanan dengan metode Productivity and Susceptibility (PSA). Hasil dari kajian ini nantinya dapat dijadikan sebagai acuan untuk pengelolaan sumber daya rajungan dan mencegah kepunahan.

\section{MATERI DAN METODE}

Materi yang digunakan dalam penelitian ini adalah 200 ekor rajungan yang ditangkap di perairan Desa Tunggulsari, Rembang. Metode yang digunakan dalam penelitian ini adalah metode Productivity and Susceptibily Analysis (PSA). Wawancara diakukan kepada 60 nelayan Desa Tunggulsari pada tanggal 7 Januari 2020 sampai 6 Februari 2020. Pengukuran parameter kualitas air dilakukan di perairan Desa Tunggulsari dengan mengukur suhu, pH, salinitas, dan DO pada tanggal 28 Januari 2020. Pengukuran morfometri rajungan dilakukan di salah satu pengepul di Desa Tunggulsari pada tanggal 27 dan 28 Januari 2020. Data pengukuran yang diambil yaitu pengukuran berat tubuh rajungan dengan menggunakan neraca analitik, lebar, dan panjang karapas rajungan dengan menggunakan jangka sorong. Pengukuran panjang dan lebar karapas menggunakan jangka sorong dengan ketelitian 0,01 $\mathrm{mm}$ dan berat rajungan ditimbang dengan menggunakan neraca analitik dengan ketelitian 0,1 gram.

Analisa PSA membutuhkan data berupa parameter biologis rajungan, yaitu umur pertama matang gonad, umur maksimum, kesuburan, kematian, kematian alamiah, dan tingkah laku rajungan. Selanjutnya untuk wawancara dilakukan kepada nelayan secara acak. Atribut yang dikumpulkan merupakan data kerentanan meliputi ketersediaan, kemampuan tertangkap, selektivitas, dan kematian pasca tangkap. Atribut data produktvitas dan kerentanan tersedia dalam Tabel 1 dan 2. Produktivitas dan kerentanan ditentukan dengan memberikan nilai rendah sampai tinggi (1-3) untuk satu set standar atribut setiap indeks. Data diperoleh melalui penelitian setelah pengelompokkan sesuai dengan skor (Tabel 3).

Penilaian produktivitas ditentukan dengan pertumbuhan spesies, karakteristik tingkat kematangan, trophic level, dan fekunditas. Atribut produktivitas dan nilai disajikan pada Tabel 4. 
Kerentanan dinilai berdasarkan kelebihan dari daerah penangkapan dibandingkan dengan kisaran spesies (penyebaran geografis dan kedalaman atau habitat) atau ketersediaan, kemungkinan tertangkap (ukuran spesies dengan mesh size), selektivitas alat tangkap, dan kematian pasca tangkap.

Atribut dari nilai produktivitas untuk penentuan analisis risiko digunakan sesuai dengan produktivitas dari biota yang dianalisis. Nilai dapat ditentukan berdasarkan dari produktivitas rajungan dengan literatur yang ada, maka akan didapat nilai dari setiap karakteristik yang terdapat dalam produktivitas rajungan.

Lebih lanjut, analisa hubungan lebar dan berat rajungan dapat diketahui mencari nilai $b$. Hipotesis digunakan sebagai berikut: (1) Jika $b=3$, maka pola pertumbuhan rajungan adalah isometrik, (2) Jika $b \neq 3$, maka pola pertumbuhan rajungan adalah allometrik, dimana $b<3$ adalah allometrik negatif atau $b>3$ adalah allometrik positif.

Tabel 1. Atribut Data Produktivitas

\begin{tabular}{ccc}
\hline Karakteristik & Sumber basis data & Pengumpulan data \\
\hline Rata-rata umur matang gonad & Sebaran dan diameter telur & Literatur \\
Rata-rata ukuran matang gonad & Length frequency & Data Penelitian \\
Rata-rata umur maksimum & Length frequency & Literatur \\
Rata-rata ukuran maksimum & Length frequency & Data Penelitian \\
Fekunditas & Telur rajungan & Literatur \\
Strategi Reproduksi & Diameter telur & Literatur \\
Trofik level & Food habit & Literatur
\end{tabular}

Sumber: Lestari (2013)

Tabel 2. Atribut Data Kerentanan

\begin{tabular}{ccc}
\hline Karakteristik & Sumber basis data & Pengumpulan Data \\
\hline Ketersediaan & Distribusi & Kuesioner \\
Kemampuan tertangkap & Distribusi & Kuesioner \\
Selektivitas & Distribusi & Kuesioner \\
Kematian pasca tangkap & Morfologi & Kuesioner \\
\hline
\end{tabular}

Sumber: Aisyah et al. (2019)

Tabel 3. Keterangan Penilaian

\begin{tabular}{ll}
\hline & Dibagi berdasarkan dua parameter, produktivitas dan kerentanan \\
dengan nilai berkisar 1-3 & Produktivitas \\
& $1=$ Tinggi \\
& $2=$ Sedang \\
3 & $=$ Rendah \\
& Kerentanan \\
& $1=$ Rendah \\
& $2=$ Sedang \\
& $3=$ Tinggi
\end{tabular}

Sumber: Aisyah et al. (2019) 


\section{HASIL DAN PEMBAHASAN}

Desa Tunggulsari terletak di Kecamatan Kaliori, Kabupaten Rembang, Jawa Tengah dan berbatasan langsung dengan Kabupaten Pati. Mayoritas warga Desa Tunggulsari berprofesi sebagai nelayan. Tangkapan utama di Desa Tunggulsari adalah rajungan. Nelayan menggunakan 2 jenis alat tangkap yaitu bubu lipat (badong) dan jaring insang dasar (pejer). Bubu lipat yang digunakan berukuran $50 \mathrm{~cm} \times 30 \mathrm{~cm} \times 18 \mathrm{~cm}$ dengan bahan jaring senar polyethylene yang memiliki ukuran mata jaring sebesar 1,75 inch. Dalam sekali operasi, nelayan biasa membawa $500-600$ bubu lipat. Umpan yang digunakan adalah kepala ikan. Jaring insang dasar yang digunakan untuk menangkap rajungan adalah jaring yang sudah dimodifikasi dengan menambahkan 2 rangkap jaring dengan ukuran mata jaring yang semakin ke dalam semakin kecil. Dalam sekali penangkapan, nelayan membawa 20 jaring. Beberapa nelayan membawa kedua alat tangkap ini pada saat melakukan penangkapan ini.

Nelayan biasa berangkat melaut pada pukul 04.00 dan kembali pada pukul 10.00. Lokasi penangkapan rajungan berjarak 1-10 mil dari daratan. Pada lokasi penangkapan dilakukan pengukuran parameter kualitas air laut dengan hasil pada Tabel 5.

Hasil pengukuran parameter kualitas air laut menunjukkan bahwa kondisi perairan Desa Tunggulsari merupakan habitat rajungan. Migrasi yang dilakukan oleh rajungan relatif jauh, hal ini menyebabkan rajungan dapat mentolerir rentang salinitas yang cukup tinggi. Pemijahan rajungan biasa dilakukan pada daerah yang memiliki salinitas relatif tinggi, namun pada saat dewasa rajungan mencari makan pada perairan dengan salinitas rendah. Hal ini menunjukkan hasil tangkapan nelayan mayoritas merupakan rajungan dewasa (Santoso et al., 2016). Alat tangkap yang digunakan oleh nelayan Desa Tunggulsari ada 2, yaitu bubu atau biasa disebut oleh warga lokal badong dan jaring rajungan atau pejer. Pengoperasian kedua alat tangkap ini memiliki kesamaan yaitu diletakkan pada dasar perairan dan ditinggalkan selama 24 jam. Dari keseluruhan nelayan $48 \%$ menggunakan alat tangkap bubu lipat, $12 \%$ menggunakan jaring, dan $40 \%$ nelayan menggunakan kedua alat tersebut. Menurut nelayan setempat, alat tangkap rajungan yang dianggap lebih efektif adalah bubu.

Tabel 4. Atribut dan nilai produktivitas untuk penentuan analisis resiko

\begin{tabular}{|c|c|c|c|}
\hline Karakteristik & $\begin{array}{l}\text { Produktivitas } \\
\text { rendah (Resiko } \\
\text { tinggi, Nilai=3) }\end{array}$ & $\begin{array}{c}\text { Produktivitas sedang } \\
\text { (Resiko sedang, } \\
\text { Nilai=2) }\end{array}$ & $\begin{array}{c}\text { Produktivitas tinggi } \\
\text { (Resiko rendah, } \\
\text { Nilai=1) }\end{array}$ \\
\hline $\begin{array}{l}\text { Rata-rata umur matang } \\
\text { gonad }\end{array}$ & $>15$ tahun & 5-15 tahun & $<5$ tahun \\
\hline Rata-rata umur maksimum & $>25$ tahun & 10-25 tahun & $<10$ tahun \\
\hline Fekunditas & $<100$ telur/tahun & $\begin{array}{l}100-20.000 \\
\text { telur/tahun }\end{array}$ & >20.000 telur/tahun \\
\hline $\begin{array}{l}\text { Rata-rata ukuran } \\
\text { maksimum }\end{array}$ & $>300 \mathrm{~cm}$ & $100-300 \mathrm{~cm}$ & $<100 \mathrm{~cm}$ \\
\hline $\begin{array}{l}\text { Rata-rata ukuran matang } \\
\text { gonad }\end{array}$ & $>200 \mathrm{~cm}$ & $40-200 \mathrm{~cm}$ & $<40 \mathrm{~cm}$ \\
\hline $\begin{array}{l}\text { Strategi reproduksi } \\
\text { Torfik Level }\end{array}$ & $\begin{array}{l}\text { Live bearer } \\
>3,25\end{array}$ & $\begin{array}{l}\text { Demersal egg layer } \\
2,75-3,25\end{array}$ & $\begin{array}{l}\text { Broadcast spawner } \\
<2,75\end{array}$ \\
\hline
\end{tabular}

Sumber: WWF (2013)

Tabel 5. Parameter perairan lokasi penangkapan Rajungan (Portunus pelagicus)

\begin{tabular}{llll}
\hline \multicolumn{1}{c}{ Parameter } & \multicolumn{1}{c}{ Kisaran } & \multicolumn{1}{c}{ Referensi } & \multicolumn{1}{c}{ Sumber Data } \\
\hline Suhu $\left({ }^{\circ} \mathrm{C}\right)$ & $29-30$ & $27-30$ & Ernawati et al. $(2014)$ \\
Salinitas $(\% \circ)$ & 22 & $20-36$ & Zaidin et al. $(2013)$ \\
DO $(\mathrm{mg} / \mathrm{l})$ & 8,47 & $5,1-9,2$ & Susanto $(2007)$ \\
pH & 8,5 & $7,5-8,5$ & Effendy (2006) \\
\hline
\end{tabular}


Hal ini dikarenakan bubu menggunakan umpan untuk memancing rajungan masuk perangkap dan rajungan tidak mudah lolos karena ukuran mata jaringnya. Sedangkan untuk pengoperasian alat tangkap jaring rajungan ditinggalkan tanpa umpan. Kedua alat ini dipasang pada kedalaman 6 - 10 meter sesuai dengan habitat rajungan karena rajungan hidup mulai dari perairan pantai hingga laut lepas dengan kedalaman mencapai 50 sampai lebih dari 65 meter (Ernawati et al., 2014).

Pemberian nilai untuk atribut produktivitas didapatkan dari literatur, sedangkan untuk atribut kerentanan didapatkan dari hasil wawancara kepada nelayan Desa Tunggulsari dan sekitarnya. Wawancara dilakukan kepada 60 nelayan dengan rentang usia 19 - 65 tahun. Nilai produktivitas dari rajungan yang diperoleh dari data sekunder disajikan pada Tabel 6 . Lebih lanjut, pemberian nilai kerentanan rajungan yang tertangkap dengan bubu lipat dan jaring dapat dilihat berturut-turut pada Tabel 7 dan 8.

Hasil penilaian atribut kerentanan pada kedua alat tangkap masuk pada kategori tinggi pada karakteristik ketersediaan dan kemampuan tertangkap. Hal ini dikarenakan rajungan berada di habitat utama yaitu pada dasar perairan dan berada pada kedalaman yang sama, sehingga pada setiap sekali operasi terdapat rajungan yang tertangkap bubu lipat ataupun jaring. Selektivitas bubu lipat masuk daam kategori tinggi karena mesh size dari bubu lipat sebesar 1,75 inch sehingga rajungan yang sudah masuk ke dalam perangkap sulit untuk melepaskan diri. Berbeda dengan selektivitas alat tangkap jaring, rajungan yang tertangkap jaring akan dapat masuk dan keluar dengan mudah karena alat tangkap jaring relatif terbuka dibandingkan dengan bubu lipat yang merupakan perangkap. Rajungan hasil tangkapan nelayan dijual ke pengepul dalam keadaan hidup, sehingga nilai kematian pasca tangkapnya adalah 1 dengan kategori rendah.

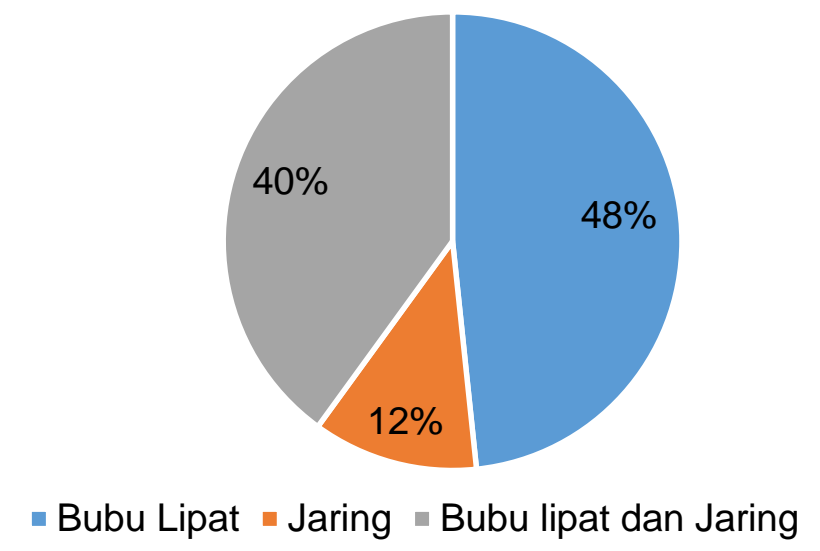

Gambar 1. Diagram penggunaan alat tangkap nelayan Desa Tunggulsari

Tabel 6. Nilai atribut produktivitas Rajungan (Portunus pelagicus)

\begin{tabular}{|c|c|c|c|c|}
\hline Karakteristik & $\begin{array}{c}\text { Rajungan } \\
\text { ( } P \text {. pelagicus) }\end{array}$ & Nilai & Kategori & Referensi \\
\hline $\begin{array}{l}\text { Rata-rata umur matang } \\
\text { gonad }\end{array}$ & $<1$ tahun & 1 & Rendah & De Lestang et al. (2003) \\
\hline Rata-rata umur maksimum & $2,5-3$ tahun & 1 & Rendah & Josileen dan Menon (2007) \\
\hline Fekunditas & $\begin{array}{l}213.333- \\
3.376 .666 \\
\text { telur/tahun }\end{array}$ & 1 & Rendah & Polity et al. (2011) \\
\hline Rata-rata ukuran maksimum & 159 mm & 2 & Sedang & - \\
\hline $\begin{array}{l}\text { Rata-rata ukuran matang } \\
\text { gonad }\end{array}$ & 92 mm & 2 & Sedang & - \\
\hline Strategi Reproduksi & $\begin{array}{l}\text { Broadcast } \\
\text { spawner }\end{array}$ & 1 & Rendah & $\begin{array}{l}\text { Stergiou dan Karpouzi } \\
\text { (2002) }\end{array}$ \\
\hline Trofik level & 2,62 & 1 & Rendah & $\begin{array}{l}\text { Stergiou dan Karpouzi } \\
\text { (2002) }\end{array}$ \\
\hline
\end{tabular}


Tabel 7. Nilai atribut kerentanan Rajungan (Portunus pelagicus) yang tertangkap dengan bubu lipat

\begin{tabular}{|c|c|c|c|}
\hline Karakteristik & Hasil penelitian & $\begin{array}{c}\text { Atribut } \\
\text { Skor }\end{array}$ & Kategori \\
\hline Ketersediaan & $100 \%$ berada habitat utama & 3 & Tinggi \\
\hline Kemampuan tertangkap & $100 \%$ berada pada kedalaman yang sama & 3 & Tinggi \\
\hline Selektivitas & $\begin{array}{l}\text { Dapat masuk tetapi tidak dapat dengan } \\
\text { mudah melepaskan diri dari perangkap }\end{array}$ & 3 & Tinggi \\
\hline Kematian pasca tangkap & $100 \%$ hidup & 1 & Rendah \\
\hline
\end{tabular}

Tabel 8. Nilai atribut kerentanan Rajungan (Portunus pelagicus) yang tertangkap dengan jaring insang dasar

\begin{tabular}{llll}
\hline \multicolumn{1}{c}{ Karakteristik } & \multicolumn{1}{c}{ Hasil penelitian } & $\begin{array}{c}\text { Atribut } \\
\text { Skor }\end{array}$ & \multicolumn{1}{c}{ Kategori } \\
\hline Ketersediaan & $100 \%$ berada habitat utama & 3 & Tinggi \\
Kemampuan tertangkap & $\begin{array}{l}100 \% \text { berada pada kedalaman yang sama } \\
\text { Sapat masuk dan keluar dengan mudah } \\
\text { Sari perangkap }\end{array}$ & 3 & $\begin{array}{l}\text { Tinggi } \\
\text { Kelivitas }\end{array}$ \\
Kematian pasca tangkap & $100 \%$ hidup & 1 & Sedang \\
\hline
\end{tabular}

Total skor produktivitas Rajungan (Portunus pelagicus) dalam Tabel 9 adalah sebesar 1,29, sedangkan total skor kerentanan Rajungan ( $P$. pelagicus) dengan alat tangkap bubu (badong) sebesar 1,65 dan dengan alat tangkap jaring (pejer) sebesar 1,43. Lebih lanjut, hasil pengelompokan nilai atribut produktivitas dan kerentanan dengan penggunaan alat tangkap bubu dan jaring dapat dilihat pada Tabel 9.

Hasil interpolasi kedalam variabel MSC (Marine Sterwardship Counci) untuk memperoleh nilai MSC, diperoleh hasil yaitu 93,4 dan 96,1 atau $>80$. Hasil nilai MSC ini menunjukkan bahwa tingkat kerentanan rajungan di Perairan Desa Tunggulsari Kabupaten Rembang termasuk pada kategori kerentanan rendah. Atribut produktivitas dan kerentanan secara keseluruhan menghasilkan nilai PSA yang dapat dilihat pada grafik PSA. Dengan penggunaan kedua alat ini, rajungan masih masuk ke dalam kategori kerentanan rendah, karena walaupun pada atribut kerentanan mayoritas masuk pada kategori tinggi, namun produktivitas pada perairan tergolong tinggi, sehingga dapat mengimbangi penangkapan yang dilakukan oleh nelayan. Berbeda dengan hasil penelitian Susanto (2006), rajungan di Perairan Kabupaten Maros, Sulawesi Selatan dinilai sudah mengalami penangkapan berlebih (overfishing). Hal ini dikarenakan penangkapan yang dilakukan oleh nelayan kabupaten maros telah melewati jumlah upaya penangkapan lestari, sehingga produksi penangkapan nelayan berkurang dan rajungan pada lokasi tersebut terancam punah. Untuk tetap menjaga tingkat kerentanan rendah pada rajungan ini, nelayan harus mentaati Peraturan Menteri Kelautan dan Perikanan Nomor 1/PERMEN-KP/I/2015 atau dalam Surat Edaran Menteri Kelautan dan Perikanan Nomor 18/MEN-K/I/2015 yang menyatakan penangkapan Rajungan (Portunus pelagicus) dapat dilakukan dengan ukuran lebar karapas $>100 \mathrm{~mm}$ atau dengan ukuran berat $>55$ gram.

Pengukuran morfometri rajungan hasil tangkapan nelayan Desa Tunggulsari dilakukan di salah satu pengepul sebanyak 200 ekor rajungan terdiri dari 110 ekor rajungan jantan dan 90 ekor rajungan betina. Distribusi panjang karapas selama penelitian menunjukkan panjang minimum dari total rajungan yang diamati adalah $32 \mathrm{~mm}$ untuk rajungan jantan dan $34 \mathrm{~mm}$ untuk rajungan betina. Sedangkan panjang karapas maksimum adalah $64 \mathrm{~mm}$ untuk rajungan jantan dan $61 \mathrm{~mm}$ untuk rajungan betina. Selanjutnya, lebar karapas minimum untuk rajungan jantan dan betina berturutturut adalah $66 \mathrm{~mm}$ dan $77 \mathrm{~mm}$. Lebar karapas maksimum rajungan jantan adalah $138 \mathrm{~mm}$, dan rajungan betina adalah $134 \mathrm{~mm}$. Berat rajungan terkecil untuk rajungan jantan dan betina berturutturut adalah 17 gram dan 27 gram. Sedangkan berat rajungan terbesar untuk rajungan jantan dan betina berturut-turut adalah 179 gram dan 177 gram. Distribusi panjang, lepar, dan berat rajungan dapat dilihat pada Gambar 3, 4, dan 5. 


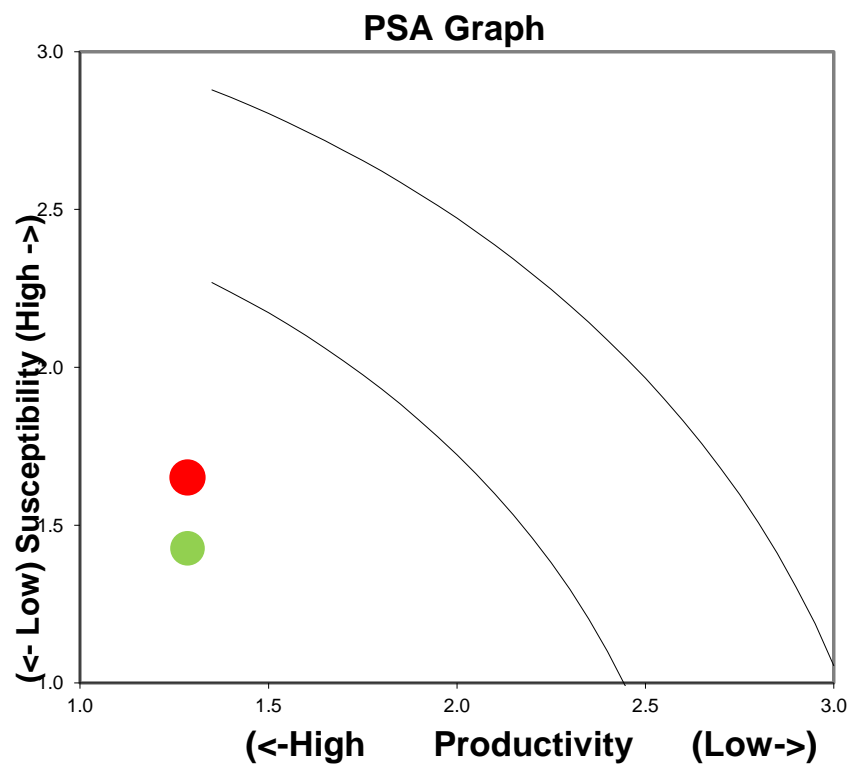

Gambar 2. Kurva Grafik PSA Rajungan di Desa Tunggulsari yang ditangkap menggunakan. Keterangan: $\bigcirc$ = bubu (badong); $\bigcirc$ = jaring (pejer)

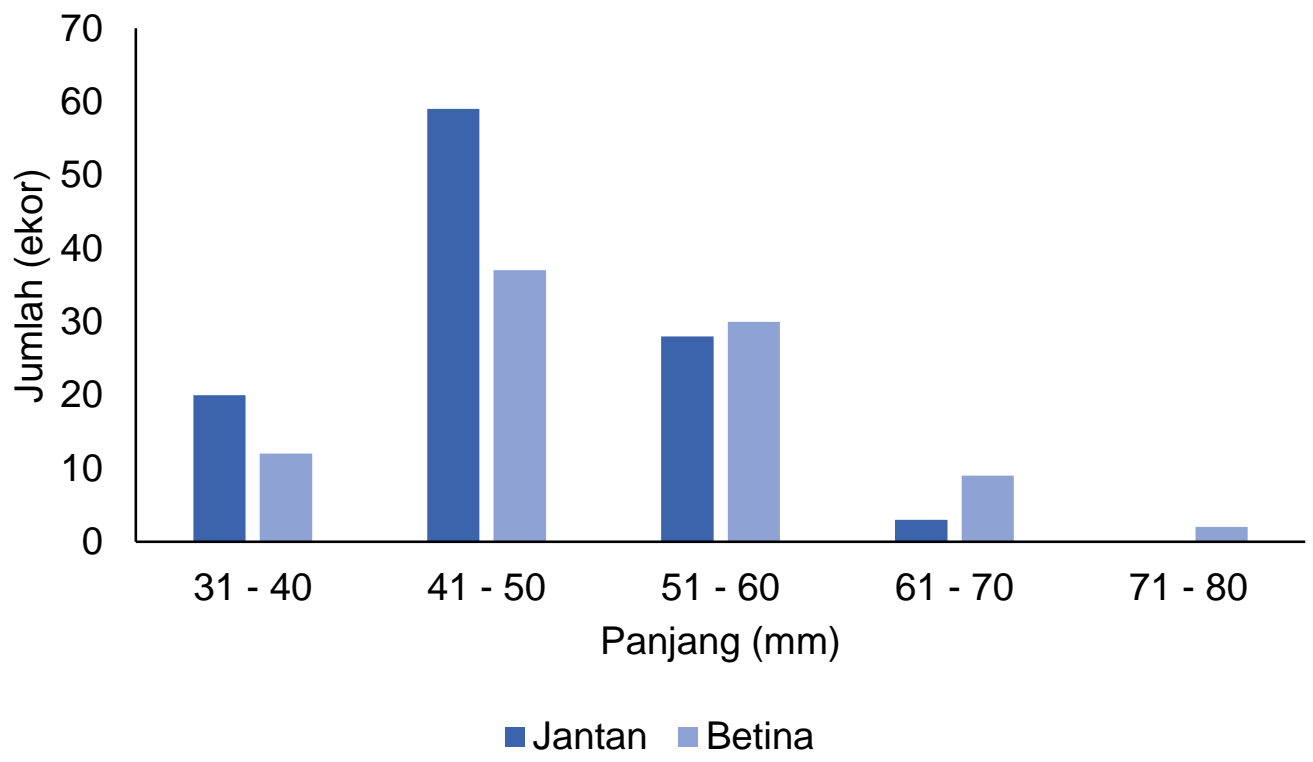

Gambar 3. Distribusi panjang karapas Rajungan ( $P$. pelagicus) berdasarkan kelasnya di Desa Tunggulsari

Dari hasil tangkapan Rajungan ( $P$. pelagicus) yang diidentifikasi didapatkan nilai rata-rata panjang karapas Rajungan ( $P$. pelagicus) adalah 47,23 mm untuk jantan dan 50,77 untuk betina. Selanjutnya, dari hasil tangkapan Rajungan ( $P$. pelagicus) yang diidentifikasi didapatkan nilai ratarata lebar Rajungan ( $P$. pelagicus) sebesar 102,73 mm untuk jantan dan 106,67 mm untuk betina. Rata-rata lebar rajungan baik rajungan jantan maupun rajungan betina pada perairan Desa Tunggulsari Rembang ini sedikit lebih kecil dibandingan dengan rajungan yang ditangkap di perairan Dusun Ujung Lombok Timur. Pada penelitian Santoso et al. (2016) mengatakan bahwa rata-rata lebar rajungan yang tertangkap adalah $118,2 \mathrm{~mm}$ untuk rajungan jantan dan $124,1 \mathrm{~mm}$ untuk rajungan betina. Hasil analisa hubungan panjang karapas, lebar karapas, dan berat rajungan di Desa Tunggulsari diperoleh dari persamaan regresi linier pada Gambar 6. Dari persamaan tersebut maka dapat disimpulkan pola pertumbuhan rajungan di Desa Tunggulsari yang dapat dilihat pada 
Tabel 9.

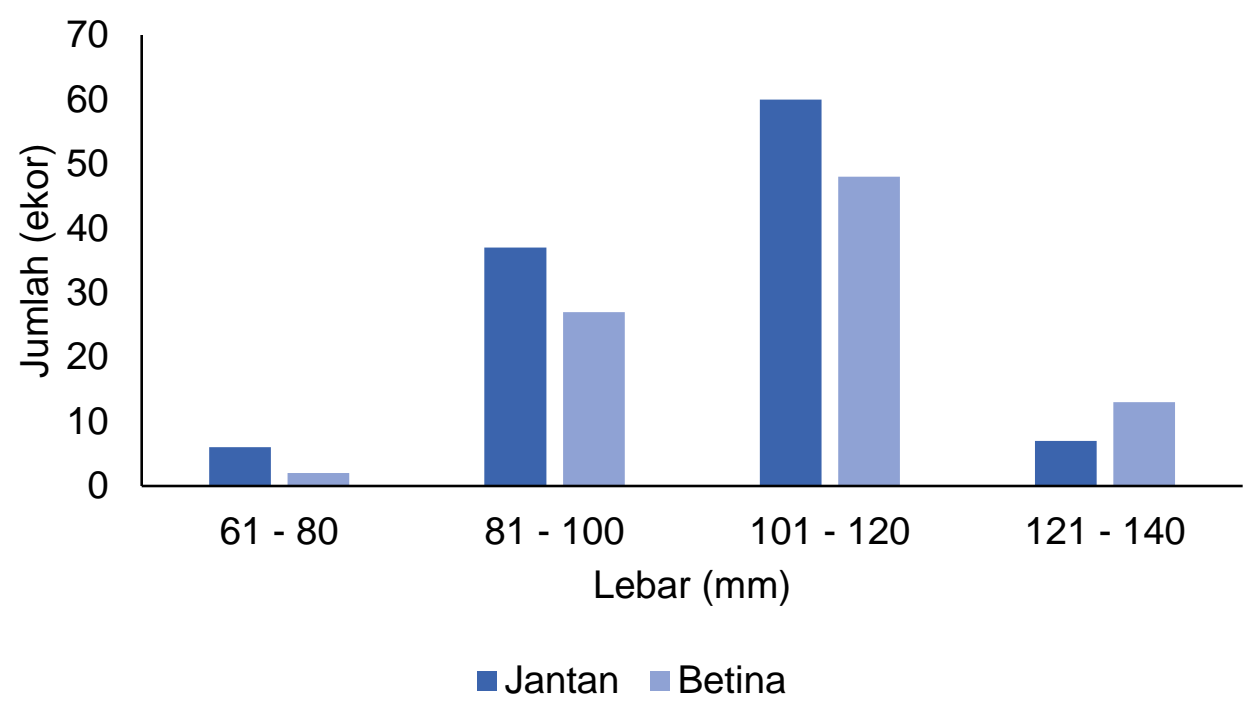

Gambar 4.Distribusi lebar karapas Rajungan ( $P$. pelagicus) berdasarkan kelasnya di Desa Tunggulsari

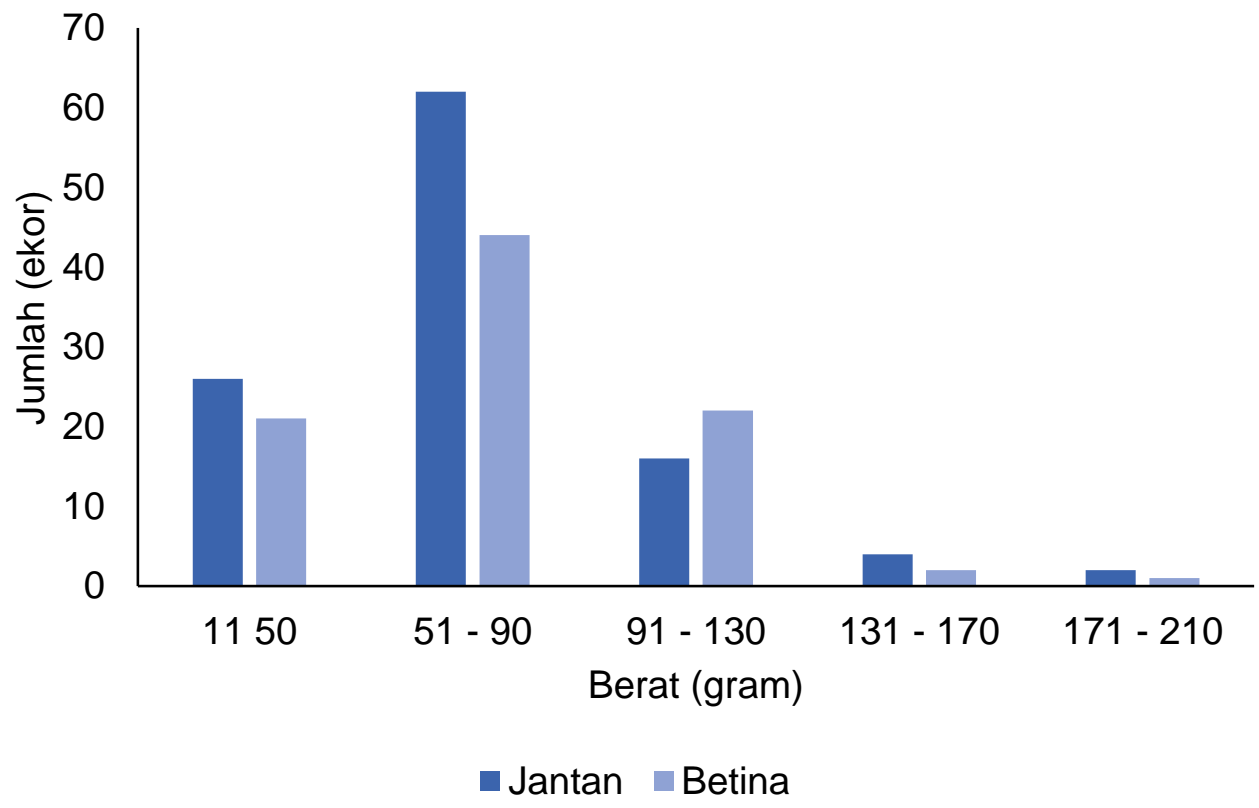

Gambar 5. Distribusi berat Rajungan ( $P$. pelagicus) berdasarkan kelasnya di Desa Tunggulsari

Nilai indeks pertumbuhan (b) pada rajungan jantan lebih besar dari rajungan betina. Hal ini menunjukkan bahwa pertumbuhan rajungan jantan lebih cepat dibandingkan dengan rajungan betina. Pada hubungan antara panjang karapas dengan berat rajungan jantan didapatkan nilai $b$ sebesar 2,80 dengan hasil pola pertumbuhan allometrik negatif dan dapat disimpulkan bahwa pertumbuhan panjang karapas rajungan jantan lebih cepat dibandingkan penambahan beratnya. Sedangkan pada hubungan antara panjang karapas dengan berat rajungan betina didapatkan nilai b sebesar 2,05 dengan hasil pola pertumbuhan allometrik negatif dan dapat disimpulkan bahwa pertumbuhan panjang karapas betina lebih cepat dibandingkan penambahan beratnya.

Selanjutnya, hubungan antara panjang karapas dan berat rajungan. Hubungan antara lebar karapas dan berat rajungan juga termasuk pada pola pertumbuhan allometrik negatif. Pada rajungan jantan, nilai b yang diperoleh adalah sebesar 2,97 dan pada rajungan betina, nilai b yang diperoleh adalah 2,86. Kedua nilai $b$ ini menunjukkan pola pertumbuhan allometrik negatif yang berarti lebar karapas tumbuh lebih cepat dibandingkan dengan berat rajungan. Berbeda dengan hasil penelitian 
di perairan Pati yang menunjukkan hasil bahwa rajungan pada lokasi tersebut memiliki pola pertumbuhan allometrik positif dimana penambahan berat rajungan lebih cepat dibandingkan dengan pertumbuhan lebar karapas (Ernawati et al., 2014). Secara umum, perbedaan lokasi habitat rajungan dapat mengakibatkan perbedaan pola pertumbuhan. Menurut Ernawati et al. (2014), perbedaan pola pertumbuhan rajungan dapat dipengaruhi oleh beberapa faktor, seperti jenis kelamin, proses reproduksi, suhu perairan, salinitas, hingga makanan dari rajungan tersebut, baik jumlah, kualitas, ataupun ukurannya.

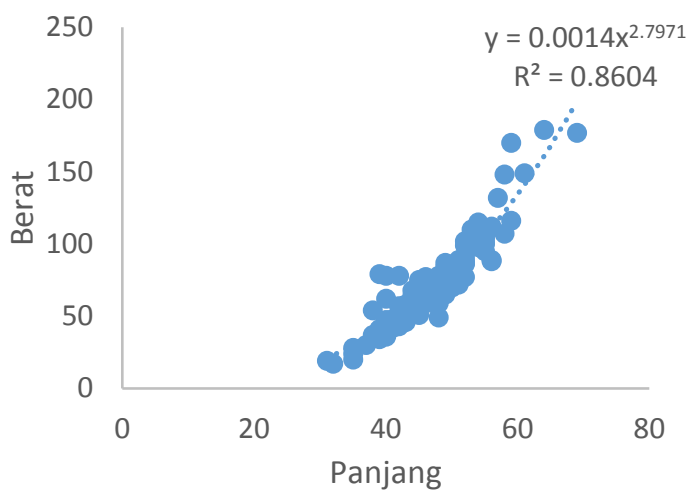

(a)

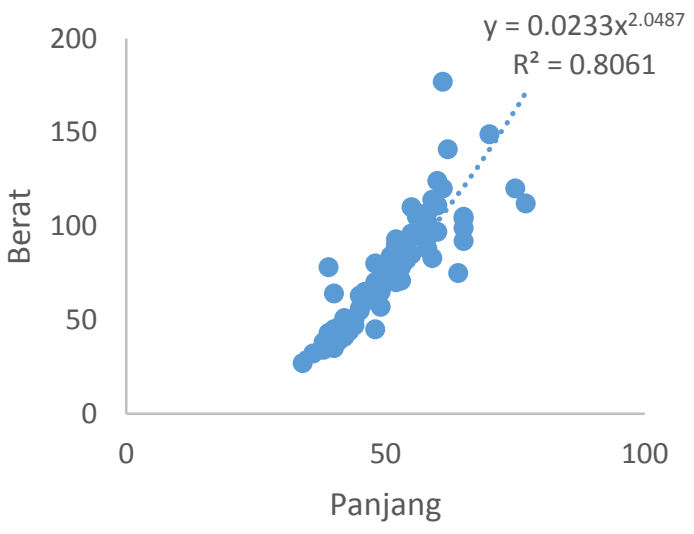

(c)

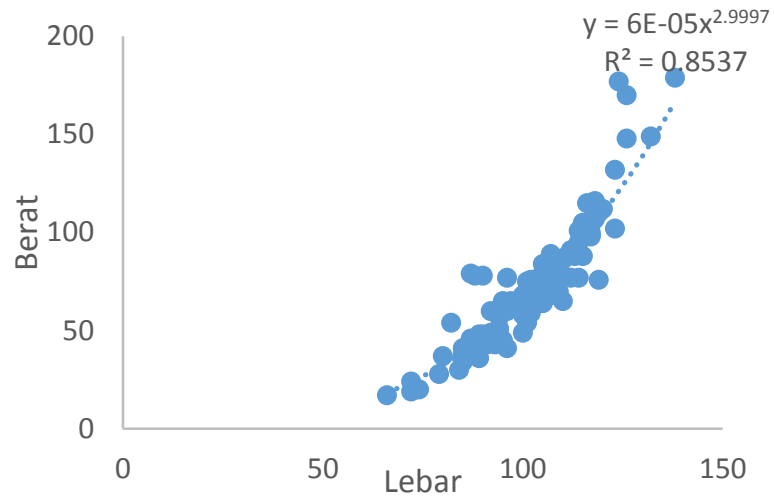

(b)

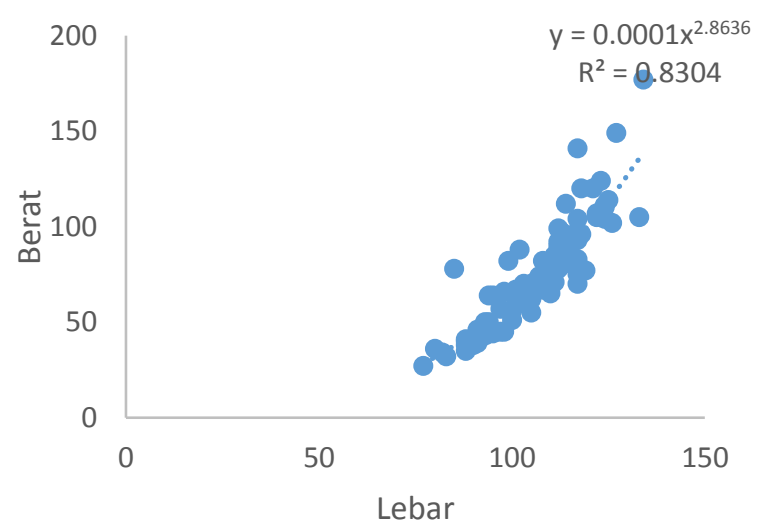

(d)

Gambar 6. (a) Hubungan panjang karapas dan berat rajungan jantan; b) Hubungan lebar karapas dan berat rajungan jantan; (c) Hubungan panjang karapas dan berat rajungan betina;

(d) Hubungan lebar karapas dan berat rajungan betina

Tabel 9. Hubungan panjang - berat dan lebar - berat Rajungan (Portunus pelagicus) pada penelitian

\begin{tabular}{llcccl}
\hline \multicolumn{1}{c}{$\begin{array}{c}\text { Hubungan/ Jenis } \\
\text { kelamin }\end{array}$} & $\begin{array}{c}\text { Jumlah } \\
\text { individu }\end{array}$ & Nilai b & $\mathrm{R}^{2}$ & $\mathrm{R}$ & Pola Pertumbuhan \\
\hline $\begin{array}{l}\text { Panjang - berat } \\
\text { Jantan }\end{array}$ & 110 & 2,7971 & 0,8604 & 0,9276 & Allometrik negatif \\
Betina & 90 & 2,0487 & 0,8061 & 0,8978 & Allometrik negatif \\
& & & & & \\
Lebar - berat & 110 & 2,9997 & 0,8537 & 0,9240 & Allometrik negatif \\
Jantan & 90 & 2,8636 & 0,8304 & 0,9113 & Allometrik negatif \\
Betina & & & & & \\
\hline
\end{tabular}


Hasil penelitian ini sama seperti penelitian yang dilakukan oleh Andriani et al. (2015), dimana rajungan yang didaratkan di Kelurahan Kampung Bugis Kota Tanjungpinang memiliki pola pertumbuhan allometrik negatif. Berbeda dengan hasil penelitian yang dilakukan oleh Permatahati et al. (2019), rajungan di Perairan Bungin Permai, Konawe Selatan, Sulawesi Tenggara, baik untuk rajungan jantan atau betina di zona intertidal dan zona seagrass memiliki pola pertumbuhan isometrik. Pola pertumbuhan isometrik adalah pola pertumbuhan dimana pertambahan lebar seimbang dengan pertambahan berat rajungan.

Nilai $r$ pada hubungan panjang karapas jantan dengan berat dan hubungan panjang karapas betina dengan berat berturut-turut adalah sebsar 1,6725 dan 1,4313 yang menunjukkan adanya ikatan yang sangat kuat pada pertumbuhan panjang karapas dengan berat rajungan baik pada rajungan jantan maupun rajungan betina. Selanjutnya, nilai $r$ pada hubungan lebar karapas jantan dengan berat dan hubungan lebar karapas betina dengan berat berturut-turut adalah sebesar 1,7320 dan 1,6922 yang juga menunjukkan adanya ikatan yang sangat kuat pada pertumbuhan lebar karapas dengan berat rajungan baik pada rajungan jantan maupun rajungan betina.

\section{KESIMPULAN}

Berdasarkan hasil penelitian yang dilakukan, tingkat kerentanan Rajungan (Portunus pelagicus) dengan menggunakan alat tangkap bubu dan jaring rajungan termasuk pada kategori kerentanan rendah. Nilai PSA untuk alat tangkap bubu dan jaring rajungan berturut-turut adalah 1,93 dan 1,74. Sedangkan untuk nilai MSC untuk alat tangkap bubu dan jaring rajungan berturut-turut adalah 96,0 dan 98,2 atau > 80 dan menunjukkan bahwa tingkat kerentanan rajungan di Perairan Desa Tunggulsari Kabupaten Rembang termasuk pada kategori kerentanan rendah. Hal ini menunjukkan bahwa kondisi stok rajungan pada daerah tersebut masih dapat berlanjut dengan memperhatikan aspek lestari dari rajungan itu sendiri. Selanjutnya untuk karakteristik rajungan di Perairan Desa Tunggulsari yaitu allometrik negatif, baik untuk rajungan jantan maupun rajungan betina. Hal ini menunjukkan bahwa pertumbuhan panjang dan lebar karapas lebih cepat dibandingkan penambahan berat rajungan.

\section{DAFTAR PUSTAKA}

Aisyah, A., Triharyuni, S., Prianto, E. \& Husnah, H., 2019. Kajian Resiko Kepiting Bakau (Scylla Serrata) Di Estuari Mahakam, Kalimantan Timur. Jurnal Penelitian Perikanan Indonesia, 25(1):15-26.

Andriani, Y., Zulfikar, A. \& Raza'l, T.S. 2015. Kajian Stok Rajungan (Portunus pelagicus, Linn) yang Didaratkan Di Kelurahan Kampung Bugis Kecamatan Tanjung Pinang Kota Kota Tanjungpinang Provinsi Kepulauan Riau. Repositiry Umrah.

de Lestang, S., Hall, N.G. \& Potter, I.C., 2003. Reproductive biology of the blue swimmer crab (Portunus pelagicus, Decapoda: Portunidae) in five bodies of water on the west coast of Australia. Fishery Bulletin, 101(4):745-757..

Dudi, T.J., Tadjuddah, M. \& Arami, H. 2019. Productivity and Susceptibility Analysis of Yellowfin Tuna (Thunnus albacares) landed at Sodohoa Fishing Base, Kendari City, Indonesia. IOP Conf. Series: Earthand Environmental Science 253, pp. 1-7. DOI: 10.1088/17551315/253/1/012025.

Ernawati, T., Boer, M. \& Yonvitner, Y. 2014. Biologi Populasi Rajungan (Portunus pelagicus) di Perairan Sekitar Wilayah Pati, Jawa Tengah. Bawal : Widya Riset Perikanan Tangkap, 6(1): 31-40.

Josileen, J. \& Menon, N.G., 2007. Fishery and growth parameters of the blue swimmer crab Portunus pelagicus (Linnaeus, 1758) along the Mandapam coast, India. Journal of the Marine Biological Association of India, 49(2), pp.159-165.. 
Kurnia, R. \& Boer, M., 2014. Biologi populasi rajungan (Portunus Pelagicus) dan karakteristik lingkungan habitat esensialnya sebagai upaya awal perlindungan di Lampung Timur. Jurnal IImu Pertanian Indonesia, 19(1):22-28.

Patanda, M., Wisudo, S.H., Monintja, D.R. \& Wiryawan, B., 2017. Sustainability for reef fish resource based on productivity and susceptibility in Wangi-Wangi Island, Southeast Sulawesi, Indonesia. Aquaculture, Aquarium, Conservation \& Legislation, 10(4):861-874.

Permatahati, Y.I., Sara, L. \& Yusnaini, Y. 2019. Hubungan Lebar Karapas dan Bobot Tubuh Rajungan (Portunus pelagicus) pada Zona Intertidal dan Zona Seagrass di Perairan Bungin Permai, Konawe Selatan, Sulawesi Tenggara Indonesia. Jurnal Sains dan Inovasi Perikanan, 3(1):1-8.

Polity, I.A., Muhamad, J.H., Long, S.M. \& Bolong, A.M.A., 2011. Fecundity of blue swimming crab, Portunus pelagicus Linnaeus, 1758 from Sematan fishing district, Sarawak coastal water of South China Sea. Borneo Journal of Resource Science and Technology, 1(1):46-51.

Santoso, D. \& Raksun, A 2016. Karakteristik Bioekologi Rajungan (Portunus pelagicus) di Perairan Dusun Ujung Lombok Timur. Jurnal Biologi Tropis, 16(2): 94-105.

Setiyowati, D. 2016. Kajian Stok Rajungan (Portunus pelagicus) di Perairan Laut Jawa Kabupaten Jepara. Jurnal Disprotek, 7(1):84-97.

Stergiou, K.I. \& Karpouzi, V.S., 2002. Feeding habits and trophic levels of Mediterranean fish. Reviews in fish biology and fisheries, 11(3):217-254.

Susanto. 2006. Kajian Bioekonomi Sumberdaya Kepiting Rajungan (Portunus pelagicus) di Perairan Kabupaten Maros, Sulawesi Selatan. Jurnal Agrisistem, 2(2): 55-67.

World Wildlife Fund (WWF). 2013. Kajian Pendugaan Stok serta Permodelan Ekosistem Kepiting Bakau di Indonesia. 